\title{
FAKTOR-FAKTOR YANG BERPENGARUH TERHADAP PENDAPATAN PENGRAJIN SONGKOK DI KECAMATAN GRESIK KABUPATEN GRESIK
}

\section{Riskia Habiba Usman}

Program Studi Manajemen - Fakultas Ekonomi dan Bisnis

Universitas Muhammadiyah Gresik

\begin{abstract}
The purpose of this research is to identify the influence factors of income's craftmen songkok in District Gresik. This research used 48 respondents as samples. Primer data were used in this research. This research tested four independent variables, namely asset, productivity, work experience and kreativity which effected dependent variable, income. This research is also to find out the effect of asset, productivity, work experience and kreativity toward income by using two-way linear regression method. The result of the research showed that asset and work experience significantly affect income, while productivity and kreativity not significantly affect income.
\end{abstract}

Key word : asset, productivity, work experience, kreativity and income

\section{PENDAHULUAN}

Tabel 1.1

Rekap Jumlah UMKM Kabupaten Gresik Tahun 2011-2015

\begin{tabular}{|l|l|l|l|l|l|}
\hline Pengusaha & $\mathbf{2 0 1 1}$ & $\mathbf{2 0 1 2}$ & $\mathbf{2 0 1 3}$ & $\mathbf{2 0 1 4}$ & $\mathbf{2 0 1 5}$ \\
\hline Mikro & 162.319 & 163.959 & 165.616 & 167.273 & 168.946 \\
\hline \multirow{2}{*}{ Kecil } & 17.344 & 17.570 & 17.748 & 17.926 & 18.106 \\
\hline \multirow{2}{*}{ Menengah } & 1.422 & 1.477 & 1.452 & 1.467 & 1.482 \\
\hline \multirow{2}{*}{ Total } & 181.085 & 183.006 & 184.816 & 186.666 & 188.534 \\
\hline
\end{tabular}

Sumber : Diskoperindag Kab. Gresik

Data tabel 1.1 menunjukkan bahwa jumlah UMKM yang terdaftar pada Dinas Koperasi Perindustrian dan Perdagangan (DISKOPERINDAG) Kabupaten Gresik, selalu meningkat tiap tahunnya. Maka tidak mengherankan apabila Kabupaten Gresik memiliki banyak produk unggulan. Menurut Hari Wahyudi SE, MM, selaku Kasi pemodalan DISKOPERINDAG Kab. Gresik, salah satu produk unggulan
Kabupaten Gresik yaitu songkok. Gresik sudah dikenal sebagai sentralnya produksi songkok nasional dan menembus pasar internasional. Industri songkok di Gresik di mulai dari masa keemasan pada tahun 70-an, di mana awal kerajinan songkok ini berasal. Kerajinan songkok di Gresik berpusat di Kec. Gresik (dapat dilihat pada tabel 1.2) atas dasar tersebut peneliti menggunakan objek 51 


\begin{tabular}{|c|l|c|}
\hline No & $\begin{array}{c}\text { Nama } \\
\text { Kecamatan }\end{array}$ & $\begin{array}{c}\text { Jumlah } \\
\text { UMKM }\end{array}$ \\
\hline 1 & Gresik & 51 \\
\hline 2 & Kebomas & 2 \\
\hline 3 & Sidayu & 3 \\
\hline 4 & Benjeng & 2 \\
\hline 5 & $\begin{array}{l}\text { Duduk } \\
\text { Sampeyan }\end{array}$ & 2 \\
\hline 6 & Bungah & 8 \\
\hline 7 & Manyar & 3 \\
\hline 8 & Panceng & 2 \\
\hline 9 & Ujung & 2 \\
\hline 10 & Dangkah & 2 \\
\hline 11 & Kedamean & 1 \\
\hline 12 & Cerme & 4 \\
\hline Jumlah Total & $\mathbf{8 2}$ \\
\hline
\end{tabular}

UMKM pengrajin songkok yang tersebar di kec. Gresik.

Tabel 1.2

Jumlah UMKM Songkok Kecamatan

Gresik Berdasarkan Kecamatan

Sumber : DISKOPERINDAG Kab. Gresik

Menurut Erik pelaku usaha songkok daerah Kemuteran Gresik beberapa tahun terakhir pengusaha songkok mengalami kesulitan dalam mendapatkan stok bahan bludru, sebelumnya pengrajin bisa membeli stok bahan bludru terlebih dahulu dengan sistem hutang, namun kini supplier menerapkan sistem pembelian bludru dengan sistem bayar di muka. Sehingga pengrajin yang tidak memiliki modal, cukup kesulitan untuk memproduksi songkok lebih banyak. Sawir $(2009 ; 23)$ modal kerja adalah keseluruhan aktiva lancar yang dimiliki oleh perusahaan atau dapat pula dimaksudkan dana yang harus tersedia untuk membiayai operasi perusahaan. Menurut Armin pada Paramita dan Budhiasa (2014) Modal

memiliki hubungan yang poisitif dengan pendapatan dimana, jika modal di tambah untuk memperbesar usaha maka pendapatan yang di dapatkan semakin meningkat.

Menurut yang diungkapkan Ahmad Irwan selaku pengusaha songkok di daerah Kroman Gresik, produktivitas pengrajin songkok mengalami penurunan tiap tahunnya, dikarenakan permintaan pasar yang menurun, sebelumnya selama bulan puasa permintaan songkok meningkat mencapai $80 \%$ dari bulan biasa, sedangkan untuk beberapa tahun trakhir ini peningkatan hanya mencapai 30-40\% saja. Hal ini didukung juga oleh pernyataan Erik pelaku usaha songkok daerah Kemuteran Gresik yang juga menyatakan produktivitas songkok menurun.

Pengrajin UMKM Songkok Kecamatan Gresik yang ada di Kec. Gresik memiliki berbagai jenis motif songkok yang berbeda-beda antara satu UMKM dengan UMKM lain. Mulai dari songkok khusus anakanak dengan berbagai gambar kartun, sampai songkok bermotif grup sepak bola. Hal ini memperlihatkan bahwa perlunya adanya Kreativitas dalam mengembangkan usaha UMKM Songkok.

Menurut Simanjuntak pada jurnal Wardhana dan Natha (2014), Faktor lain yang juga berpengaruh terhadap pendapatan tetapi tidak digunakan di dalam model penelitian ini yaitu jam kerja, teknologi, tenaga kerja, tingkat upah, modal dan umur. Jam kerja tidak digunakan karena pengrajin songkok umumnya menggunakan sistem borongan. Teknologi tidak digunakan karena para pengrajin songkok kecamatan Gresik belum memproduksi songkok menggunakan teknologi yang terlalu 
rumit. Tenaga kerja dan tingkat upah tidak digunakan karena tenaga kerja pada pengrajin songkok umumnya bukan tenaga kerja tetap. Umur tidak digunakan karena belum ada fenomena menarik yang peneliti dapatkan.

Dengan adanya fenomena diatas, maka penelitian ini ingin mengetahui pengaruh Antara modal kerja, produktivitas, pengalaman kerja dan kreativitas terhadap tingkat pendapatan pengrajin songkok di Kabupaten Gresik.

\section{METODOLOGI PENELITIAN Pendekatan Penelitian}

Pendekatan ini menggunakan pendekatan kuantitatif. Dalam memperoleh data dan informasi yang dibutuhkan untuk membahas permasalahan, maka penelitian ini dilakukan pada UMKM Pengrajin Songkok di Kecamatan Gresik, Kabupaten Gresik.

\section{Populasi}

Jumlah yang dijadikan populasi oleh peneliti adalah Seluruh UMKM pengrajin songkok Kecamatan Gresik Kabupaten Gresik dengan jumlah 51 UMKM.

\section{Jenis Dan Sumber Data}

Dalam penyusunan penelitian jenis data yang digunakan oleh peneliti adalah data primer dan data sekunder. Data primer adalah data yang diperoleh dari hasil wawancara langsung dengan responden yaitu kepada 48 pemilik UMKM Songkok Kecamatan Gresik Kecamatan Gresik. Data sekunder yang dibutuhkan diperoleh dari dinas pasar dan lembaga-lembaga terkait.

\section{Definisi Operasional Variabel}

Definisi operasional variabel merupakan batasan dalam menjelaskan variabel yang digunakan dalam penelitian, sehingga terarah pada pokok permasalahan yang akan diteliti. Pada penelitian ini menggunakan beberapa batasan variabel yaitu:

1. Modal Kerja $\left(\mathrm{x}_{1}\right)$

2. Produktivitas $\left(\mathrm{x}_{2}\right)$

3. Pengalaman Kerja $\left(\mathrm{x}_{3}\right)$

4. Kreativitas $\left(\mathrm{x}_{4}\right)$

5. Pendapatan $(\mathrm{Y})$

\section{Teknik Analisis Data}

Dalam penelitian ini menggunakan teknik analisis data regresi linear berganda. Teknik ini untuk mengetahui arah hubungan antara variabel independen dan variabel dependen, apakah masing-masing variabel-variabel independen berpengaruh positif atau negatif dan untuk memprediksi nilai dari variabel dependen apabila nilai variabel independen mengalami kenaikan atau penurunan. Berdasarkan tujuan dan hipotesis penelitian diatas, maka variabelvariabel dalam penelitian ini akan dianalisis dengan bantuan software SPSS pada regresi linear berganda.

\section{Pengujian Hipotesis}

\section{Uji Signifikan Parsial (Uji t)}

Uji statistik $t$ pada dasarnya menunjukkan seberapa jauh pengaruh satu variabel independent secara individual dalam menerangkan variasi variabel dependen (Ghozali 2013;98).

\section{HASIL PENELITIAN \\ Deskriptif Hasil Penelitian}

1. Gambaran Umum Responden Penelitian

Analisis ini bertujuan untuk memperoleh data karakteristik 
demografik responden, yang meliputi usia, jenis kelamin, dan pendidikan. Adapun gambaran yang diperoleh mengenai karakteristik demografik responden penelitian disajikan dalam tabel berikut ini :

\section{Karakteristik Responden} berdasarkan usia

\section{Tabel 4.1}

Karakteristik Berdasarkan Usia.

\begin{tabular}{|c|c|c|c|}
\hline \multirow{2}{*}{ No } & \multirow{2}{*}{ Usia } & \multicolumn{2}{|c|}{ Jumlah } \\
\cline { 3 - 4 } & & Frekuensi & Presentase \\
\hline 1 & $30-39$ & 7 & 15 \\
\hline 2 & $40-49$ & 32 & 67 \\
\hline 3 & $50-57$ & 9 & 19 \\
\hline \multicolumn{2}{|c|}{ Jumlah } & 48 & 100 \\
\hline
\end{tabular}

Sumber: Data primer diolah 2016

Berdasarkan tabel 4.1 dapat diketahui bahwa dari segi usia, responden yang berusia 40-49 tahun memperoleh jumlah terbesar sebanyak $67 \%$. Hal ini menyatakan bahwa pemilik UMKM Songkok Kecamatan Gresik kebanyakan telah berkeluarga dan pada saat usia yang lanjut, usaha akan di alihkan kepada anaknya.

2. Karakteristik Berdasarkan Jenis Kelamin

Tabel 4.2

Karakteristik Berdasarkan Jenis

Kelamin

\begin{tabular}{|c|c|c|c|}
\hline \multirow{2}{*}{$\begin{array}{l}\mathrm{N} \\
\mathrm{O}\end{array}$} & \multirow{2}{*}{$\begin{array}{c}\text { Jenis } \\
\text { Kelamin }\end{array}$} & \multicolumn{2}{|c|}{ Jumlah } \\
\hline & & $\begin{array}{c}\text { Frekuen } \\
\text { si }\end{array}$ & $\begin{array}{c}\text { Presenta } \\
\text { se }\end{array}$ \\
\hline 1 & Laki-laki & 45 & 94 \\
\hline 2 & $\begin{array}{c}\text { Perempu } \\
\text { an }\end{array}$ & 3 & 6 \\
\hline \multicolumn{2}{|r|}{ Jumlah } & 48 & 100 \\
\hline
\end{tabular}

Sumber: Data primer diolah 2016

Berdasarkan tabel 4.2 menunjukan bahwa responden terbesar berjenis kelamin laki-laki yaitu sebanyak 94\%. Hal ini menyatakan bahwa
UMKM Songkok Kecamatan Gresik merupakan usaha yang membutuhkan tenaga yang lebih dalam melaksanakan usaha, mulai dari produksi, pendistribusian dan pengambilan bahan baku.

\section{Karakteristik Berdasarkan} Pendidikan

Tabel 4.3

Karakteristik Berdasarkan Pendidikan

\begin{tabular}{|c|c|c|c|}
\hline \multirow{2}{*}{ No } & \multirow{2}{*}{ Usia } & \multicolumn{2}{|c|}{ Jumlah } \\
\cline { 3 - 4 } & & Frekuensi & Presentase \\
\hline 1 & SMP & 9 & 19 \\
\hline 2 & SMA & 27 & 56 \\
\hline 3 & Diploma & 8 & 17 \\
\hline 4 & Sarjana & 4 & 8 \\
\hline \multicolumn{2}{|c|}{ Jumlah } & 48 & 100 \\
\hline
\end{tabular}

Sumber: Data primer diolah 2016 Berdasarkan tabel 4.3 tersebut menunjukan bahwa responden terbesar adalah berpendidikan SMU sebanyak 27 atau sebesar $56 \%$ dari keseluruhan responden berjumlah 48 .

\section{Rekapitulasi Tangapan}

\section{Responden}

1. Berdasarkan hasil kuesioner pernyataan pertama diperoleh skor total 180 yang berarti sebagian besar pemilik UMKM Songkok Kecamatan Gresik setuju bahwa mudah dalam mendapatkan modal.

2. Berdasarkan hasil kuesioner pernyataan kedua diperoleh skor 173 yang berarti sebagian besar pemilik UMKM Songkok Kecamatan Gresik setuju bahwa modal yang dimiliki sudah sesuai kebutuhan produksi.

3. Berdasarkan hasil kuesioner pernyataan ketiga diperoleh skor total 177 yang berarti sebagian besar pemilik UMKM Songkok Kecamatan Gresik setuju 
mengalami peningkatan modal kerja setiap tahunnya.

4. Berdasarkan hasil kuesioner pernyataan pertama diperoleh skor total 174 berarti sebagian besar pemilik UMKM Songkok Kecamatan Gresik setuju bahwa merasa bangga dengan usaha yang dijalani.

5. Berdasarkan hasil kuesioner pernyataan kedua diperoleh skor total 186 yang berarti sebagian besar pemilik UMKM Songkok Kecamatan Gresik setuju bahwa dalam menguasai keterampilan yang sangat baik dalam melaksanakan usaha.

6. Berdasarkan hasil kuesioner pernyataan ketiga diperoleh skor total 180 yang berarti sebagian besar pemilik UMKM Songkok Kecamatan Gresik setuju dalam menjaga ketepatan waktu.

7. Berdasarkan hasil kuesioner pernyataan keempat diperoleh skor total 179 yang berarti sebagian besar pemilik UMKM Songkok Kecamatan Gresik setuju mutu dari hasil kerja yang dikerjakan selalu memenuhi standar yang ditetapkan.

8. Berdasarkan hasil kuesioner pernyataan kelima diperoleh skor total 184 yang berarti sebagian besar pemilik UMKM Songkok Kecamatan Gresik setuju selalu berusaha untuk meningkatkan kualitas usaha.

9. Berdasarkan hasil kuesioner pernyataan keenam diperoleh skor total 183 yang berarti sebagian besar pemilik UMKM Songkok Kecamatan Gresik setuju dan tidak merasa berat terhadap beban yang menjadi tanggung jawab pengrajin

10. Berdasarkan hasil kuesioner pernyataan ketujuh diperoleh skor total 188 yang berarti sebagian besar pemilik UMKM Songkok Kecamatan Gresik setuju tidak merasa jenuh terhadap usaha yang di tangani.

11. Berdasarkan hasil kuesioner pernyataan kedelapan diperoleh skor total 198 yang berarti sebagian besar pemilik UMKM Songkok Kecamatan Gresik setuju untuk selalu berusaha memperbaiki terhadap kesalahan yang pernah dilakukan dalam melaksanakan usaha.

12. Berdasarkan hasil kuesioner pernyataan kesembilan diperoleh skor total 178 yang berarti sebagian besar pemilik UMKM Songkok Kecamatan Gresik setuju bahwa jumlah dari hasil pekerjaan yang di tangani selalu memenuhi target yang di tetapkan.

13. Berdasarkan hasil kuesioner pernyataan pertama diperoleh skor total 180 yang berarti sebagian besar pemilik UMKM Songkok Kecamatan Gresik setuju pengalaman kerja membantu mengurangi kesalahankesalahan yang di lakukan pada saat menjalankan usaha.

14. Berdasarkan hasil kuesioner pernyataan kedua diperoleh skor total 188 yang berarti sebagian besar pemilik UMKM Songkok Kecamatan Gresik setuju usaha yang di lakukan saat ini, sangat membutuhkan pengalaman kerja yang di miliki.

15. Berdasarkan hasil kuesioner pernyataan ketiga diperoleh skor total 178 yang berarti sebagian besar pemilik UMKM Songkok Kecamatan Gresik setuju dalam tidak membuang waktu dengan kegiatan lain yang tidak berkaitan dengan usaha. 
16. Berdasarkan hasil kuesioner pernyataan keempat diperoleh skor total 177 yang berarti sebagian besar pemilik UMKM Songkok Kecamatan Gresik setuju dalam menjalankan usaha selalu menyelesaikan pekerjaan dengan tepat waktu.

17. Berdasarkan hasil kuesioner pernyataan kelima diperoleh skor total 188 yang berarti sebagian besar pemilik UMKM Songkok Kecamatan Gresik setuju bahwa selalu bekerja sesuai dengan prosedur yang sudah di tetapkan.

18. Berdasarkan hasil kuesioner pernyataan pertamadiperoleh skor total 204 yang berarti sebagian besar pemilik UMKM Songkok Kecamatan Gresik sangat setuju bahwa selalu tertarik terhadap pengalaman baru.

19. Berdasarkan hasil kuesioner pernyataan kedua diperoleh skor total 180 yang berarti sebagian besar pemilik UMKM Songkok Kecamatan Gresik setuju bahwa tidak kehabisan ide dalam memecahkan masalah.

20. Berdasarkan hasil kuesioner pernyataan ketiga diperoleh skor total 196 yang berarti sebagian besar pemilik UMKM Songkok Kecamatan Gresik setuju bahwa memiliki ide yang berasal dari pemikiran sendiri.

21. Berdasarkan hasil kuesioner pernyataan keempat diperoleh skor total 198 yang berarti sebagian besar pemilik UMKM Songkok Kecamatan Gresik setuju mempunyai rasa ingin tahu yang besar.

22. Berdasarkan hasil kuesioner pernyataan kelima diperoleh skor total 189 yang berarti sebagian besar pemilik UMKM Songkok
Kecamatan Gresik setuju bahwa fleksibel dalam berpikir.

23. Berdasarkan hasil kuesioner pernyataan keenam diperoleh skor total 192 yang berarti sebagian besar pemilik UMKM Songkok Kecamatan Gresik setuju bahwa fleksibel dalam merespon.

24. Berdasarkan hasil kuesioner pernyataan ketujuhdiperoleh skor total 200 yang berarti sebagian besar pemilik UMKM Songkok Kecamatan Gresik setuju menggunakan waktu luang untuk kegiatan yang bermanfaat sebagai pengembangan kemampuan pengrajin.

25. Berdasarkan hasil kuesioner pernyataan pertama diperoleh skor total 170 yang berarti sebagian besar pemilik UMKM Songkok Kecamatan Gresik setuju pendapatan pengrajin selalu memenuhi target yang ditetapkan.

26. Berdasarkan hasil kuesioner pernyataan keempat diperoleh skor total 171 yang berarti sebagian besar pemilik UMKM Songkok Kecamatan Gresik setuju pendapatan pengrajin mengalami peningkatan setiap tahunnya.

\section{Analisis Data}

Analisis data yang digunakan dalam penelitian ini adalah regresi linier berganda dengan Pendapatan (Y) sebagai variabel terikat. Variabelvariabel bebasnya adalah Modal Kerja (X1), Produktivitas (X2), Pengalaman Kerja (X3), dan Kreativitas (X4). Analisis ini digunakan untuk mengetahui apakah variabel Modal Kerja $\left(\mathrm{X}_{1}\right)$, Produktivitas $\left(\mathrm{X}_{2}\right), \quad$ Pengalaman Kerja $\left(\mathrm{X}_{3}\right)$, dan Kreativitas $\left(\mathrm{X}_{4}\right)$ berpengaruh terhadap Pendapatan (Y) pada UMKM Songkok 
Kecamatan Gresik Kecamatan Gresik. Hasil analisis regresi linier berganda dengan menggunakan SPSS yang dapat dilihat pada tabel dibawah ini:

Tabel 4.16

Hasil Regresi Linier Berganda

Coefficients $^{a}$

\begin{tabular}{|c|c|c|c|c|c|c|}
\hline \multirow[t]{2}{*}{ Model } & & \multicolumn{2}{|c|}{ Unstandardized Coefficients } & \multirow{2}{*}{$\begin{array}{c}\begin{array}{c}\text { Standardized } \\
\text { Coefficients }\end{array} \\
\text { Beta }\end{array}$} & \multirow[b]{2}{*}{$t$} & \multirow[b]{2}{*}{ Sig. } \\
\hline & & $B$ & Std. Error & & & \\
\hline \multirow[t]{5}{*}{1} & (Constant) & -1.929 & 1.510 & & -1.277 & .208 \\
\hline & $x_{1}$ & .219 & .087 & .284 & 2.526 & .015 \\
\hline & $x_{2}$ & -.022 & .079 & -.054 & -.281 & .780 \\
\hline & $x_{3}$ & .411 & .106 & .687 & 3.875 & .000 \\
\hline & $x_{4}$ & -.014 & .041 & -.029 & -341 & .735 \\
\hline
\end{tabular}

Berdasarkan tabel 4.15, maka dapat diperoleh persamaan regresi berganda adalah sebagai berikut :

$\mathrm{Y}=-1,929+0,219 \mathrm{X}_{1}-0,022 \mathrm{X}_{2}+$ $0,422 X_{3}-0,014 X_{4}$

1. Jika nilai Konstanta $(\alpha)=-1,929$ menunjukkan bahwa, jika variabel modal kerja (X1), produktivitas (X2), pengalaman kerja (X3) dan kreativitas (X4), bernilai 0 , maka besarnya variabel pendapatan( $\mathrm{Y}$ ) adalah sebesar -1,929 satuan.

2. Jika modal kerja (X1) berubah dengan satu satuan nilai, maka Y akan berubah sebesar 0,219 satuan nilai, dengan anggapan produktivitas (X2), pengalaman kerja (X3) dan kreativitas (X4) tetap, artinya semakin baik modal kerja, maka pendapatan akan semakin meningkat dengan menganggap variabel lain tetap/konstan.

3. Jika produktivitas (X2) berubah dengan satu satuan, maka Y akan berubah sebesar -0,022 satuan nilai, dengan anggapan modal (X1), pengalaman kerja (X3) dan kreativitas (X4) tetap, artinya jika produktivitas meningkat, maka pendapatan akan menurun dengan menganggap variabel lain tetap/konstan.

4. Jika pengalaman kerja (X3) berubah dengan satu satuan nilai, maka Y akan berubah sebesar 0,422 satuan nilai, dengan anggapan modal (X1), produktivitas (X2) dan kreativitas (X4) tetap, artinya semakin baik pengalaman kerja, maka pendapatan akan semakin meningkat dengan menganggap variabel lain tetap/konstan.

5. Jika kreativitas (X4) berubah dengan satu satuan, maka Y akan berubah sebesar $-0,014$ satuan nilai, dengan anggapan modal (X1), pengalaman kerja (X3) dan kreativitas (X4) tetap, artinya jika kreativitas meningkat, maka pendapatan akan menurun dengan menganggap variabel lain tetap/konstan.

\section{Uji Kelayakan Model}

\section{Uji Statistik F}

Menurut Ghozali (2013;98), uji statistik F pada dasarnya menunjukan apakah semua variabel independen atau bebas yang dimasukkan dalam model mempunyai pengaruh secara bersama-sama terhadap variabel dependen/terikat. Hipotesis nol (Ho) yang hendak diuji adalah apakah semua parameter dalam model sama dengan nol, atau:

$\mathrm{H}_{0}=$ artinya variabel independen secara simultan tidak berpengaruh terhadap variabel dependen.

$\mathrm{Ha}=$ artinya semua variabel independen secara simultan berpengaruh terhadap variabel dependen.

Kriteria pengambilan keputusan sebagai berikut: 
1. $\mathrm{H}_{0}$ diterima bila : $\mathrm{F}_{\text {hasil }} \leq \mathrm{F}_{\text {tabel }}$ dan nilai signifikansi $\geq 0.05$

2. $\mathrm{H}_{0}$ ditolak bila : $\mathrm{F}_{\text {hasil }}>\mathrm{F}_{\text {tabel }}$ dan nilai signifikansi $<0.05$

Tabel 4.17

Hasil Uji Kelayakan Model ANOVA $^{\text {b }}$

\begin{tabular}{|c|c|c|c|c|c|}
\hline Model & $\begin{array}{l}\text { Sum of } \\
\text { Squares }\end{array}$ & df & Mean Square & $\mathrm{F}$ & Sig. \\
\hline Regression & 69.926 & 4 & 17.481 & 24.603 & $.000^{\mathrm{a}}$ \\
\hline Residual & 30.553 & 43 & .711 & & \\
\hline Total & 100.479 & 47 & & & \\
\hline \multicolumn{6}{|c|}{ a. Predictors: (Constant), $X 4, X 1, X_{3}, X_{2}$} \\
\hline \multicolumn{6}{|c|}{ b. Dependent Variable: $Y$} \\
\hline $\begin{array}{l}\text { Sumber } \\
\text { diolah) }\end{array}$ & : Hasil & outp & SPS & $(\mathrm{d} z$ & \\
\hline
\end{tabular}

Berdasarkan tabel diatas dapat diperoleh angka $F_{\text {hitung }}$ lebih besar daripada $\mathrm{F}_{\text {tabel }}$ yaitu $24,605>2,59$. Dan nilai Signifikansi $0,000<$ dari 0,005, maka dapat disimpulkan bahwa modal kerja (X1), produktivitas (X2), pengalaman kerja (X3) dan kreativitas (X4) yang dimasukkan dalam model mempunyai pengaruh secara bersama-sama terhadap variabel pendapatan (Y).

\section{Koefisien Determinasi $\left(\mathbf{R}^{\mathbf{2}}\right)$}

Analisis dilakukan untuk mengetahui prosentase sumbangan pengaruh independen terhadap variabel dependen. Berikut hasil output model summary dari analisis regresi.

\section{Tabel 4.18}

Hasil Analisis Determinasi

Model Summary

\begin{tabular}{|l|c|c|c|r|}
\hline Model & $R$ & $R$ Square & $\begin{array}{c}\text { Adjusted R } \\
\text { Square }\end{array}$ & $\begin{array}{c}\text { Std. Error of } \\
\text { the Estimate }\end{array}$ \\
\hline 1 & $.834^{\mathrm{a}}$ & .696 & .668 & .843 \\
\hline
\end{tabular}

Sumber : Hasil output SPSS

Berdasarkan tabel diatas dapat diperoleh angka $\mathrm{R}^{2}$ ( $\mathrm{R}$ Square) sebesar 0,696 atau 69,6\%. Hal ini menunjukan bahwa presentase sumbangan pengaruh variabel independen terhadap variabel dependen sebesar $69,6 \%$. Sedangkan sisanya sebesar $30,1 \%$ dipengaruhi faktor lain.

\section{Pengujian Hipotesis}

Uji $t$ digunakan untuk melihat pengaruh masing-masing variabel bebas secara parsial terhadap variabel terikat. Tingkat Signifikansi $\alpha / 2=0,05 / 2=0,025$ dengan $\mathrm{df}=\mathrm{n}-\mathrm{k}-$ $1=48-4-1=43$. Jika $-\mathrm{t}$ hitung $<-\mathrm{t}$ tabelatau $t_{\text {hitung }}>t_{\text {tabel}}$, maka Ho ditolak dan Ha diterima, yang artinya ada pengaruh antara variabel $\mathrm{X}$ (bebas) dan variabel $\mathrm{Y}$ (terikat). Jika $-\mathrm{t}$ tabel $<\mathrm{t}$ hitung $<\mathrm{t}$ tabel, maka Ho diterima dan $\mathrm{Ha}$ ditolak, yang artinya tidak ada pengaruh antara variabel $\mathrm{X}$ (bebas) dan variabel $\mathrm{Y}$ (terikat) (Sugiyono,2008;192).

\section{Tabel 4.19}

\section{Hasil Uji t (Parsial)}

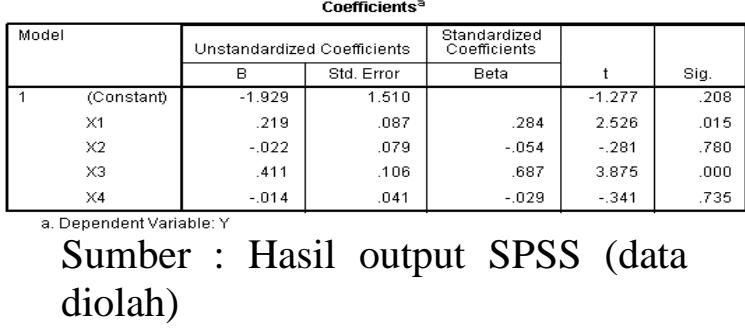

Berikut adalah gambar kurva daerah permintaan dan penolakan $\mathrm{H}_{0} \mathrm{Uji}$ t.

1. Jika $-\mathrm{t}$ hitung $<-\mathrm{t}$ tabelatau $\mathrm{t}$ hitung $>\mathrm{t}$ tabel, maka Ho ditolak dan $\mathrm{Ha}$ diterima, yang artinya ada pengaruh antara variabel $\mathrm{X}$ (bebas) dan variabel $\mathrm{Y}$ (terikat). Jika $-\mathrm{t}$ tabel $<\mathrm{t}$ hitung $<\mathrm{t}$ tabel, maka Ho diterima dan Ha ditolak, yang artinya tidak ada pengaruh antara variabel X (bebas) dan variabel Y (terikat).

Berdasarkan perhitungan diperoleh $\mathrm{t}$ hitung $(2,526)>\mathrm{t}$ tabel $(2,017)$ maka Ho ditolak dan $\mathrm{Ha}$ diterima pada tingkat signifikan $2,5 \%$ sehingga dapat diambil kesimpulan bahwa variabel modal kerja (X1) berpengaruh signifikan terhadap pendapatan (Y). 


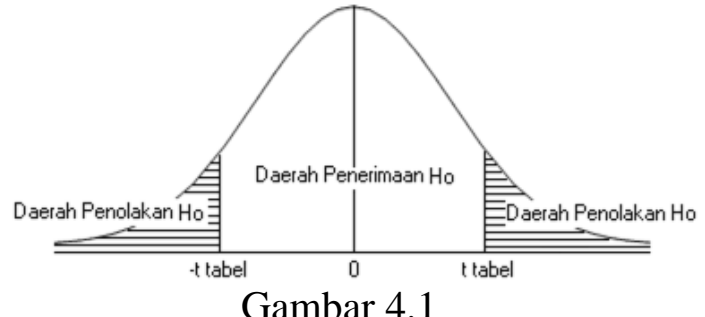

Kurva Daerah Penerimaan dan Penolakan $\mathrm{H}_{0}$ Uji t

2. Jika $-\mathrm{t}$ hitung $<-\mathrm{t}$ tabelatau $\mathrm{t}$ hitung $>\mathrm{t}$ tabel, maka Ho ditolak dan Ha diterima, yang artinya ada pengaruh antara variabel $\mathrm{X}$ (bebas) dan variabel $\mathrm{Y}$ (terikat). Jika $-\mathrm{t}$ tabel $<\mathrm{t}$ hitung $<\mathrm{t}$ tabel, maka Ho diterima dan Ha ditolak, yang artinya tidak ada pengaruh antara variabel $\mathrm{X}$ (bebas) dan variabel $\mathrm{Y}$ (terikat).

Berdasarkan perhitungan diperoleh $\mathrm{t}$ tabel ($2,017)<\mathrm{t}$ hitung $(-0,281)<\mathrm{t}$ tabel $(2,017)$ maka Ho diterima dan $\mathrm{Ha}$ ditolak pada tingkat signifikan 2,5\% sehingga dapat diambil kesimpulan bahwa variabel produktivitas (X2) tidak berpengaruh signifikan terhadap pendapatan $(\mathrm{Y})$.

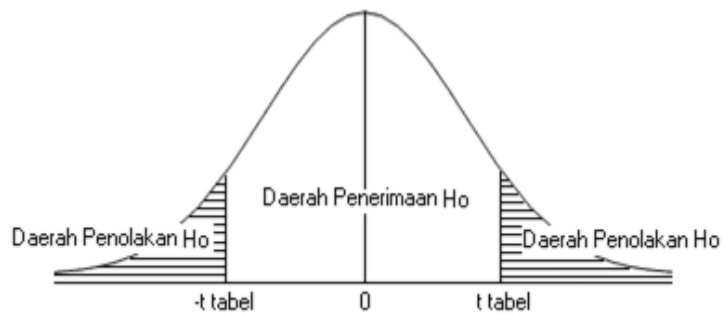

Gambar 4.2

Kurva Daerah Penerimaan dan

Penolakan $\mathrm{H}_{0}$ Uji $\mathrm{t}$

3. Jika $-\mathrm{t}$ hitung $<-\mathrm{t}$ tabel atau $\mathrm{t}$ hitung $>\mathrm{t}$ tabel, maka Ho ditolak dan $\mathrm{Ha}$ diterima, yang artinya ada pengaruh antara variabel $\mathrm{X}$ (bebas) dan variabel $\mathrm{Y}$ (terikat). Jika $-\mathrm{t}$ tabel $<\mathrm{t}$ hitung $<\mathrm{t}$ tabel, maka Ho diterima dan Ha ditolak, yang artinya tidak ada pengaruh antara variabel $\mathrm{X}$ (bebas) dan variabel $\mathrm{Y}$ (terikat). Berdasarkan perhitungan diperoleh $\mathrm{t}$ hitung $(3,875)>t_{\text {tabel }}(2,017)$ maka Ho ditolak dan $\mathrm{Ha}$ diterima pada tingkat signifikan 2,5\% sehingga dapat diambil kesimpulan bahwa variabel pengalaman kerja (X1) berpengaruh signifikan terhadap pendapatan $(\mathrm{Y})$.

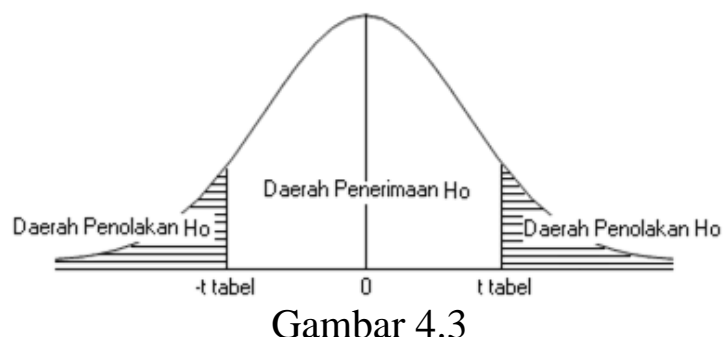

Kurva Daerah Penerimaan dan

Penolakan $\mathrm{H}_{0}$ Uji t

4. Jika $-\mathrm{t}$ hitung $<-\mathrm{t}$ tabel atau $\mathrm{t}$ hitung $>\mathrm{t}$ tabel, maka Ho ditolak dan $\mathrm{Ha}$ diterima, yang artinya ada pengaruh antara variabel $X$ (bebas) dan variabel $\mathrm{Y}$ (terikat). Jika $-\mathrm{t}$ tabel $<\mathrm{t}$ hitung $<\mathrm{t}$ tabel, maka Ho diterima dan Ha ditolak, yang artinya tidak ada pengaruh antara variabel $\mathrm{X}$ (bebas) dan variabel $\mathrm{Y}$ (terikat).

Berdasarkan perhitungan diperoleh $\mathrm{t}$ tabel ($2,017)<\mathrm{t}$ hitung $(-0,341)<\mathrm{t}$ tabel $(2,017)$ maka Ho diterima dan $\mathrm{Ha}$ ditolak pada tingkat signifikan $2,5 \%$ sehingga dapat diambil kesimpulan bahwa variabel kreativitas (X3) tidak berpengaruh signifikan terhadap pendapatan (Y).

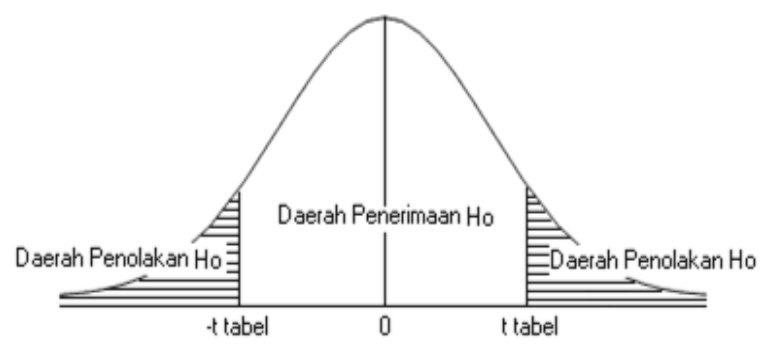

Gambar 4.4

Kurva Daerah Penerimaan dan

Penolakan $\mathrm{H}_{0}$ Uji $\mathrm{t}$ 


\section{Intrepretasi Hasil Penelitian}

Berdasarkan penelitian dan analisis yang peneliti lakukan dengan menggunakan aplikasi SPSS, maka peneliti dapat menginterpretasikan hasil pengujian hipotesis secara parsial dengan menggunakan uji $t$ antara masing-masing variabel terikat, yaitu:

1. Modal Kerja (X1)

Diperoleh hasil $t_{\text {hitung }}$ 2,526> $t_{\text {tabel }}$ 2,017 dengan tingkat signifikansi sebesar 2,5\%. Maka dapat diartikan bahwa nilai $\mathrm{t}$ hitung dari modal kerja terletak pada daerah penolakan $\mathrm{H}_{0}$ dan $\mathrm{H}_{\mathrm{a}}$ diterima berarti modal mempunyai pengaruh positif dan signifikan terhadap pendapatan Pengrajin Songkok Kecamatan Gresik. Semakin meningkat modal kerja pengrajin maka pendapatan akan semakin meningkat.

Hal ini dikarenakan kebutuhan pengrajin terhadap peningkatan modal untuk produksi. Hasil penelitian ini mendukung hasil dari peneltian Paramita dan Budhiasa (2014) bahwa modal berpengaruh secara signifikan terhadap pendapatan.

2. Produktivitas (X2)

Diperoleh hasil $\mathrm{t}$ tabel $(-2,017)<\mathrm{t}$ hitung $(-0,281)<\mathrm{t}$ tabel $(2,017)$ dengan tingkat signifikansi sebesar 2,5\%. Maka dapat diartikan bahwa nilai $\mathrm{t}$ hitung dari produktivitas terletak pada daerah penerimaan $\mathrm{H}_{0}$ dan $\mathrm{H}_{\mathrm{a}}$ ditolak berarti produktivitastidak berpengaruh signifikan terhadap pendapatan Pengrajin Songkok Kecamatan Gresik. Jika produktivitas meningkat, tidak akan berpengaruh secara signifikan terhadap pendapatan.

Karena pengrajin songkok kecamatan Gresik kebanyakan memproduksi songkok pada saat ada pesanan dengan jumlah dan waktu yang telah di sepakati, sehingga meskipun seorang pengrajin memiliki produktivitas lebih tinggi atau tidak, maka tidak akan berpengaruh terhadap jumlah pendapatan yang di terima. Menurut Blocher $\quad(2007 ; 215) \quad$ untuk meningkatkan pendapatan yang dipengaruhi oleh produktivitas harus melalui variabel volume penjualan, perubahan produktivitas output per unit akan meningkat bila terjadi peningkatan volume penjualan yang nantinya akan pengaruh terhadap pendapatan.

3. Pengalaman kerja (X3)

Diperoleh hasil $t_{\text {hitung } 3,875>t}$ tabel 2,017 dengan tingkat signifikansi sebesar 2,5\%. Maka dapat diartikan bahwa nilai $\mathrm{t}$ hitung dari pengalaman kerja terletak pada daerah penolakan $\mathrm{H}_{0}$ dan $\mathrm{H}_{\mathrm{a}}$ diterima berarti pengalaman kerja mempunyai pengaruh positif dan signifikan terhadap pendapatan Pengrajin Songkok Kecamatan Gresik.

Hal ini dikarenakan kebutuhan pengrajin terhadap pengalaman kerja, seperti menguasai keterampilan usaha, hasil kerja memenuhi standar, dan memenuhi target yang ditetapkan. Hasil penelitian ini mendukung hasil dari peneltian Wardhana dan Natha (2014) bahwa pengalaman kerja berpengaruh secara signifikan terhadap pendapatan.

4. Kreativitas (X4)

Diperoleh hasil $\mathrm{t}$ tabel $(-2,017)<\mathrm{t}$ hitung $(-0,014)<\mathrm{t}$ tabel $(2,017)$ dengan tingkat signifikansi sebesar 2,5\%. Maka dapat diartikan bahwa nilai t hitung dari kreativitas terletak pada daerah penerimaan $\mathrm{H}_{0}$ dan $\mathrm{H}_{\mathrm{a}}$ ditolak berarti kreativitas tidak berpengaruh signifikan terhadap pendapatan Pengrajin Songkok Kecamatan Gresik. Jika kreativitas meningkat, 
tidak akan berpengaruh secara signifikan terhadap pendapatan.

Hal ini dikarenakan dalam penerapannya pengrajin songkok kecamatan Gresik kebanyakan hanya memproduksi songkok sesuai dengan permintaan konsumen (made by order), sehingga meskipun pengrajin bisa lebih kreatif, namun jika konsumen hanya meminta songkok model tertentu, maka pengrajin hanya bisa membuat sesuai dengan pesanan.

\section{KESIMPULAN}

DAN

\section{REKOMENDASI}

\section{Kesimpulan}

Berdasarkan hasil peneltian tentang Faktor-Faktor Yang Berpengaruh Terhadap Pendapatan Pengrajin Songkok Di Kecamatan Gresik Kabupaten Gresik menggunakan alat analisis statistik regresi linier berganda, maka penelti dapat menyimpulkan.

1. Modal mempunyai pengaruh positif dan signifikan terhadap pendapatan pengrajin songkok Kecamatan Gresik Kabupaten Gresik. Semakin modal pengrajin mengalami kenaikan maka pendapatan pengrajin songkok Kecamatan Gresik Kabupaten Gresik semakin tinggi.

2. Produktivitas tidak berpengaruh signifikan terhadap pendapatan pengrajin songkok Kecamatan Gresik Kabupaten Gresik. Jika produktivitas meningkat, tidak akan berpengaruh secara signifikan terhadap pendapatan pengrajin songkok Kecamatan Gresik Kabupaten Gresik.

3. Pengalaman kerja mempunyai pengaruh positif dan signifikan terhadap pendapatan pengrajin songkok Kecamatan Gresik Kabupaten Gresik. Semakin pengalaman kerja pengrajin meningkat maka pendapatan pengrajin songkok Kecamatan Gresik Kabupaten Gresik semakin tinggi.

4. Kreativitas tidak berpengaruh signifikan terhadap pendapatan pengrajin songkok Kecamatan Gresik Kabupaten Gresik. Jika kreativitas meningkat, tidak akan berpengaruh secara signifikan terhadap pendapatan pengrajin songkok Kecamatan Gresik Kabupaten Gresik.

\subsection{Rekomendasi}

Terkait hasil analisis, pembahasan dan kesimpulan. maka rekomendasi yang dapat diberikan dari peneliti adalah sebagai berikut :

Bagi perusahaan :

1. Modal : Penting bagi pengrajin songkok Kecamatan Gresik untuk menjaga serta terus meningkatkan modal karena dapat meningkatkan pendapatan. Untuk meningkatkan modal, sesuai dengan Myers dalam Picking Order theory, dimana para UMKM menentuan strategi keptusan jangka panjang dalam pengadaan aset dengan laba di tahan melalui hutang. (Smart, 2004;458)

2. Pengalaman kerja : Penting bagi pengrajin songkok Kecamatan Gresik untuk menjaga serta terus meningkatkan pengalaman kerja karena dapat meningkatkan pendapatan.

Bagi peneliti selanjutnya :

Hasil penelitian ini dapat digunakan sebagai referensi bagi peneliti selanjutnya dengan memperbanyak jumlah variabel-variabelnya dan menggunakan teknik analisis yang berbeda sehingga hasil penelitian mendekati kenyataan yang sesungguhnya. 
DAFTAR PUSTAKA

Abdullah, Ma'ruf, 2014, Manajemen dan Evaluasi Kinerja Karyawan, Penerbit Aswaja Pressindo, Yogyakarta.

Ardiansyah, dkk., 2010, Pengantar Bisnis, Edisi Pertama, Graha Ilmu, Yogyakarta.

Armin, Widjaya, 2014, Anggaran Perusahaan,

AMUS, Yogyakarta.

Badan Pusat Statistik Kabupaten Gresik, 2015. BPS Kabupaten Gresik

Campbell, David, 2012, Pengembangan Kreativitas, Penerbit Kanisus, Yogyakarta.

Firdausa dan Arianti, 2013. Pengaruh Modal Awal, Lama Usaha, dan Jam Kerja Terhadap Pendapatan Pedagang Kios Di Pasar Bintaro Demak. Diponegoro Journal of Economics. Volume 2, Nomor 1, Tahun 2013. Halaman 1-6

Ghozali, Imam, 2013, Aplikasi Analisis Multivariat dengan Program IBM SPSS 21, Edisi 7, Penerbit Universitas Diponegoro, Semarang.

Handoko, T. Hani, 2012, Manajemen Personalia dan Sumber Daya Manusia, BPFE, Yogyakarta.

Kadariah, 2014, Teori Ekonomi Mikro, Fakultas Ekonomi Universitas Indonesia, Jakarta.

Mathis, Robert L., dan Jackson, Jhon H., 2009, Human Resource Management, Salemba Empat, Jakarta.

Munawir, 2014, Analisa Laporan Keuangan, Liberty, Yogyakarta.

Natha, I Ketut S., dan Wardhana, Kadek W., 2014, Faktor-Faktor Yang Berpengaruh Terhadap Pendapatan Pengrajin Industri Batu Bata di Desa Tulikup Kecamatan Gianyar, E-Jurnal EP Unud, 3 (2) : 70 - 76.
Noe, Raymond A., dkk., 2010, Manajemen Sumber Daya Manusia : Mencapai Keunggulan Bersaing, Edisi 6, Jilid 1, Salemba Empat, Jakarta.

Paramita, Ayu N., Budhiasa, I Gede S., 2014., Pengaruh Akumulasi Modal, Pendidikan, Kreativitas dan Lokasi Usaha Terhadap Pendaptan Pedagang Perempuan, E-Jurnal EP Unud, 3 (5) :182-190.

Pasaribu, Fajar, 2007, Hubungan Karakteristik Pegawai dengan Produktivitas Kerja, Jurnal Ichsan Gorontalo, 2(1): h:627637.

Pujiyanti, Fera, 2015, Rahasia Cepat Menguasai Laporan Keuangan Khusus Untuk Perpajakan dan UKM, Lembar Pustaka Indonesia, Jakarta.

Riyanto, Bambang, (2008), Dasardasar Pembelanjaan Perusahaan, Penerbit GPFE, Yogyakarta.

Sawir, 2009, Analisis Kinerja Keuangan dan Perencanaan Keuangan Perusahaan, PT Gramedia Pustaka Utama, Jakarta.

Sedarmayanti, 2011, Manajemen Sumber Daya Manusia, Reformasi Birokrasi dan. Manajemen Pegawai Negeri Sipil (cetakan kelima), PT. Refika Aditama, Bandung.

Simamora, Henry, 2014, Manajemen Sumber Daya Manusia, Edisi Ketiga, Bagian Penerbitan STIE YKPN, Yogyakarta.

Sugiyono, 2013, Metode Penelitian Kuantitatif Kualitatif dan R\&D, Alfabeta, Bandung.

Suhardjono, 2007, Manajemen Perkreditan Usaha Kecil dan Menengah. UPP AMP YKPN Ikut Mencerdaskan Bangsa, Jakarta. 
Suratmi, Epi, 2011, Pengaruh

Kreativitas dan Inovasi

Terhadap Kinerja Karyawan pada Usaha Pengrajin Rotan di Lingkungan J1. Gatot Subroto Medan

Sutrisno. 2009, Manajemen Keuangan Teori, Konsep, dan Aplikasi, Salemba Empat, Yogyakarta.

Uno, Hamzah B, 2007, Teori Motivasi dan Pengukurannya : Analisis di Bidang Pendidikan, Bumi Aksara, Jakarta.

Yunus, 2014, Mindset Revolution, Jogja Bangkit Publisher, Yogyakarta. 